\title{
W POGONI ZA PUNKTAMI, CZYLI NA CO POWINNI ZWRÓCIĆ UWAGE MLODZI NAUKOWCY
}

\section{IN THE PURSUIT OF POINTS OR WHAT YOUNG SCIENTISTS SHOULD PAY ATTENTION TO}

\author{
Sylwia Bielawska ${ }^{1(A, B, C, D, E, F, G)}$
}

${ }^{1}$ Państwowa Wyższa Szkoła Zawodowa im. Angelusa Silesiusa w Wałbrzychu

\begin{abstract}
Bielawska, S. (2018). W pogoni za punktami, czyli na co powinni zwrócić uwagę młodzi naukowcy. Rozprawy Społeczne, 12(4), 28-38. https://doi.org/10.29316/rs.2018.34

Wkład autorów:

A. Zaplanowanie badań

B. Zebranie danych

C. Dane - analiza i statystyki

D. Interpretacja danych

E. Przygotowanie artykułu

F. Wyszukiwanie i analiza

literatury

G. Zebranie funduszy

Streszczenie

Obserwowany od wielu lat nacisk na młodych naukowców, usankcjonowany przepisami prawnymi, nakłada na nich obowiązek nie tylko prowadzenia badań i działalności dydaktycznej, ale także spełnienia wymogów parametryzacyjnych. To właśnie od ilości publikacji, czasami bez względu na ich jakość, zależy ich pozycja na uczelni, a więc postęp kariery naukowej i dostęp do finansowania badań (np. uzyskania stypendium czy grantów). Nie dziwi zatem, że coraz częściej dochodzi do przypadków korzystania z kontrowersyjnych ofert tzw. drapieżnych wydawców czy organizatorów konferencji. Pozostający pod pręgierzem parametryzacyjnych wymagań naukowcy czasami nieświadomie korzystają z usług takich firm. W artykule opisano znane w świecie naukowym przypadki nieuczciwego postępowania i strategie podejmowane $\mathrm{w}$ tzw. grze parametrycznej, a także opisano rozwiązania mające zapobiec takim niepożądanym działaniom, które zapisano w procedowanej Ustawie 2.0
\end{abstract}

Tabele: 0

Ryciny: 0

Literatura: 31

Otrzymano: czerwiec 2018

Zaakceptowano: sierpień 2018
Słowa kluczowe: naukowcy, publikacje naukowe, parametryzacja, drapieżni wydawcy

\section{Summary}

The pressure on young scientists observed for many years, sanctioned by legal regulations, imposes the obligation on them not only to conduct research and teaching activities, but also to meet the requirements of parameterization. It is the number of publications, sometimes irrespective of their quality, that determines their position at the university, and thus the progress of a research career and access to research funding (i.e. obtaining scholarships or grants). Therefore, it is not surprising that cases of using controversial offers of the so-called predatory publishers or conference organisers are more frequent. Scientists that are under the pillory of parameterization requirements sometimes use such companies unknowingly. The article describes cases of dishonest behaviour known in the scientific world and strategies taken in the so-called parametric game, as well as solutions to prevent such unwanted activities, which were included in the 2.0 Act.

Keywords: scientists, scientific publications, parameterization, predatory publishers

\section{Wstęp}

Trudno nie odnieść wrażenia, że znaczna część polskiego środowiska akademickiego w ostatnich latach bierze udział $w$ niecodziennym spektaklu dostosowywania się i wzajemnego zawstydzania, zwanego parametryzacją, której podlegają dzisiaj wszystkie jednostki naukowe. Wiele wskazuje na to, że sytuacja ta szybko nie ulegnie zmianie, gdyż parametryzacja $\mathrm{z}$ narzędzia o funkcji poznawczej przekształciła się w skomplikowany mechanizm „służący zarządzaniu obszarem nauki oraz regulacji praktyk naukowych i publikacyjnych" (Ostrowicka, Spychalska-Stasiak, 2017). Przy czym mechanizm ten obciążony jest wieloma ułomnościami, słabościami, czy brakami, które wielokrotnie analizowano w literaturze przedmiotu (Brzeziński, 2016; Towpik, 2017; Wróblewski, 2017; Ostrowicka, Spychalska-Stasiak, 2017). W zasadzie osiągnęliśmy wywrotowy efekt: paramateryzacja jako jeden z najważniejszych składników ewaluacji nauki - instrument pozwalający ocenić jakość krajowych badań naukowych, który w zamyśle inicjatorów miał umożliwić prowadzenie skutecznej polityki naukowej i budować wysokiej jakości kadry naukowe dzięki swoim ułomnościom i regule powtarzalności podważa niejako jej fundamentalne założenia.

Przy tej okazji warto przypomnieć, że ocena naukowców i efektów ich pracy nie jest wynalazkiem ostatnich lat, gdyż już w połowie XX w. wraz z naro-

Adres korespondencyjny: Sylwia Bielawska, Biblioteka i Wydawnictwo Uczelniane Państwowej Wyższej Szkoły Zawodowej im. Angelusa Silesiusa, ul. Zamkowa 4, 58-300 Wałbrzych, e-mail: biblioteka@pwsz.com.pl, tel.: 7464192 26, ORCID: https://orcid.org/0000-0002-4744-9214 Copyright by: Państwowa Szkoła Wyższa im. Papieża Jana Pawła II w Białej Podlaskiej, Sylwia Bielawska

Czasopismo Open Access, wszystkie artykuły udostępniane są na mocy licencji Creative Commons Uznanie autorstwa-użycie niekomercyjne-na tych samych warunkach 4.0 Międzynarodowe (CC BY-NC-SA 4.0, http://creativecommons.org/licenses/by-nc-sa/4.0/). 
dzinami naukometrii, naukowiec i jego praca stali się elementami globalnego procesu mierzenia produktywności, opartego na wielu kryteriach oceny jakości, przygotowanych przez zespoły eksperckie. Proponowane systemy oceny (ekspercki, parametryczny) mają na celu porównać efekty badań pomiędzy różnymi instytucjami naukowymi, a także wewnątrz tej samej jednostki (np. na poziomie wydziałów czy instytutów), poprawić jakość krajowych badań, doprowadzić do globalizacji nauki oraz stworzyć płaszczyznę międzynarodowego dyskursu naukowego, a przy tym eliminować z krajowego rynku akademickiego słabsze uczelnie oraz marnych przedstawicieli różnych nauk. A ponieważ model finansowania instytucji naukowych $w$ ramach ich działalności statutowej zakłada, iż część rocznej subwencji instytucjonalnej na utrzymanie potencjału badawczego zależy w dużej mierze od osiągniętego wyniku nie dziwi zatem, że poszczególne środowiska akademickie wkładają ogromny wysiłek i środki, aby sprostać założonym oczekiwaniom. Rzecz jednak w tym, że nie zawsze wszystko idzie jak należy i w powtarzanej co kilka lat ocenie parametrycznej poszczególnych jednostek naukowych oraz indywidualnej ocenie naukowców coraz większą uwagę przywiązuje się wyłącznie do szeregu formalnych kryteriów oraz ilościowej oceny produktywności, co prowadzi do licznych nadużyć, które świadomie lub nie są popełniane w obawie przed niską oceną. Ponadto niektórzy naukowcy bardzo szybko stali się świadomi dystansu pomiędzy sobą a oczekiwanym modelem, jak również kłopotliwego uzależnienia od systemu oceny aktywności naukowej, który zależy w dużej mierze od jakości i poziomu ich produktywności naukowej. Dotyczy to zwłaszcza dwóch grup naukowców, które za Kulczyckim (2017) nazwiemy grupą średnią (ci, którzy nie są w stanie z wielu różnorodnych powodów publikować w najlepszych miejscach i osiągać wysokie wskaźniki bibliometryczne) oraz grupą niższą (naukowcy, którzy publikują niewiele lub wcale, ale system szkolnictwa wyższego nie potrafi się ich pozbyć). W konsekwencji uczelnie, aby móc funkcjonować w świecie nauki, opartym w dużej mierze na różnych wskaźnikach i parametrach, są $z$ jednej strony skazane na bezustanne dążenie do spełnienia rozmaitych wymagań stawianych w systemie oceny nauki, z drugiej zaś utrzymują świadomie w systemie także te dwie kłopotliwe grupy, zachowując pozory minimalnego poziomu skutecznej i obiektywnej rozliczalności. Jednakże na tym kwestia się nie wyczerpuje, albowiem praktykom dążenia do jak najlepszych rezultatów towarzyszy szereg niewygodnych konsekwencji w postaci problematycznych i kłopotliwych strategii obieranych przez niektórych pracowników nauki, które scharakteryzuję $\mathrm{w}$ tym artykule. W tym miejscu konieczne jest jednak pewne zastrzeżenie: omówię jedynie te strategie, które dotyczą działalności publikacyjnej stanowiącej nieodłączny atrybut pracy naukowej i działalności akademickiej pozostałe przejawy nierzetelności i nadużyć we wszelkich obszarach działalności akademickiej pozostawiając innym badaczom ${ }^{1}$.

Moja dalsza opowieść dotyczyć będzie głównie młodych naukowców, którzy rozpoczynają swoją przygodę z nauką i nieświadomi wielu zagrożeń mogą obrać nieprawidłowe wzorce kariery akademickiej: „Gdy wchodziłem do świata nauki, bardzo szybko zostało mi przekazane, że będę poddany okresowej ewaluacji, ale jest mnóstwo dróg na skróty, dzięki którym można mniej pracować, lecz i tak otrzymać pozytywną ocenę okresową czy awans. Zostało mi pokazane, że liczy się ilość, a nie jakość" (www.ekulczycki.pl/warsztat_badacza/ewaluacja -nauki-w-ustawie-2-0-moj-komentarz-na-kongresie-nauki-w-krakowie). Jeśli taki młody pracownik nauki nie spotka na początku swojej drogi Mistrza, który uświadomi mu czym jest nauka może się zdarzyć, że będzie wybierał alternatywne sposoby czy niepokojące strategie, które zapewnią mu złudzenie uczestnictwa $\mathrm{w}$ procesie nauki. Bowiem nie brak czy niedomagania są najbardziej osobliwą właściwością systemu oceny, ale jego poszczególne akty performatywne, konstytuowane przez naukowców w ramach tzw. gry parametrycznej zdefiniowanej przez Kulczyckiego (2017). I właśnie aktom tym, ze wszystkimi koniecznościami, komplikacjami i konsekwencjami chciałabym się przyjrzeć. W obawie przed ewentualnymi pozwami przedstawię te zjawiska bardzo ogólnie posiłkując się jedynie kilkoma przykładami.

\section{Geneza i reguły gry parametrycznej}

To przydługie, aczkolwiek konieczne wprowadzenie pokazuje, iż na mocy pewnych prawidłowości pole prowadzonej przez słabszych naukowców gry parametrycznej polegającej na takim prowadzeniu badań i publikowaniu ich wyników, aby wpisać się w priorytety i reguły systemu ewaluacji (Kulczycki, 2017) jest wbrew wszystkim pozorom nieograniczone. Dzieje się tak głównie z uwagi na ogólne przyśpieszenie całego świata akademickiego, który zgodnie ze słynną zasadą „publish or perish” (Nabout i in., 2014) dąży do jak najszybszej publikacji wyników badań naukowych w jak najlepszych miejscach zapewniających szybki wzrost pożądanych wskaźników bibliometrycznych (Impact Factor, indeks Hirscha bądź inne alternatywne wskaźniki, np. punkty $\mathrm{MNiSW}^{2}$ ). Czymś oczywistym i nieodzownym, po uwzględnieniu pewnych komplikacji, stało

\footnotetext{
Mam tu na myśli takie przejawy nierzetelności akademickiej, jak: pozorowane i zbędne badania, ignorancja metodologiczna, fałszowanie, zmyślanie bądź fabrykowanie danych, nierzetelne rozliczanie badań, nadużycia w procedurach grantowych, nieuczciwe raportowanie o wynikach badań, nadużycia finansowe w rozliczaniu badań, nieposzanowanie własności intelektualnej. Każde $\mathrm{z}$ wymienionych nadużyć to nie tylko temat na osobną pracę, ale i powinność w ich ujawnianiu, gdyż tylko nietolerowanie i piętnowanie takich zachowań są podstawą właściwych stosunków akademickich.

${ }^{2} \mathrm{~Np}$. istniejąca od 2005 r. punktacja ministerstwa właściwego d/s nauk i szkolnictwa wyższego, która na podstawie kolejnych rozporządzeń ministerialnych określa zasady oceny parametrycznej jednostek naukowych oraz ustala sposób punktowania poszczególnych publikacji.
} 
się podejmowanie przez słabych naukowców pewnych działań, które wskazują na fikcję pomiędzy zasadami narzuconymi przez system, a rzeczywistym przebiegiem i wynikiem parametryzacji. Wzajemne ciśnienia rodzące się pomiędzy uczelnią a naukowcem oddziaływują z obustronnymi konsekwencjami. A wszystko dlatego, że współczesna organizacja nauki kładąca ogromny nacisk na policzalność oraz rozliczalność efektów (Szadkowski, 2015), w wyniku których podejmowane są wiążące decyzje odnośnie organizacji i finansowania nauki, wymusza wręcz stosowanie upraszczających metod oceniania liczbowego. W konsekwencji tego wszystkiego zapomniano jednak „zachować zdrowy rozsądek i umiar w przydawaniu im znaczenia” (Brandt, 2011, s. 135) w pomiarze efektywności rozumianym jako zwrot inwestycji publicznych wydatkowanych na naukę. Ma się rozumieć, że w tym sensie parametryzacja jest zjawiskiem negatywnym i rodzącym liczne patologie. Zanim jednak omówimy te nieprawidłowości konieczne wydaje się znalezienie odpowiedzi na pytanie dlaczego niektórzy naukowcy godzą się na podejmowanie tej gry. Ograniczę się przy tym do dwóch zaledwie hipotetycznych sugestii w tej sprawie.

Wydaje się, że najważniejszą przyczyną podejmowanych mistyfikacji jest konieczność wpisania się na siłę $w$ akademickie strategie stosowane $w$ danej instytucji, wydziale czy jednostce. Mnożące się od lat przykłady różnorodnych limitów (w postaci np. liczby tzw. publikacji filadelfijskich, liczby cytowań czy wartości współczynnika h) obowiązujące już od momentu ubiegania się o zatrudnienie na uczelni lub w instytucie badawczym, a wszechobecne przy uczelnianych awansach czy rożnych stopniach rozwoju (np. otwierania przewodu doktorskiego czy habilitacyjnego) są i zapewne będą jeszcze przez długi czas główną przyczyną podejmowania tych wypaczonych zabiegów. Bo choć nie jest to intencjonalnie tworzony mechanizm, to nadgorliwi rektorzy, dziekani, czy dyrektorzy poszczególnych jednostek badawczych interpretują obowiązujące akty prawne odnośnie parametryzacji, które następnie na swój własny sposób starają się objaśnić. Stąd np. powszechnie znane w środowisku tzw. limity punktów, które musi zebrać kandydat na stopień naukowy lub tytuł, tak aby można było przeprowadzić określone postępowanie awansowe. W zależności od prestiżu jednostki w przypadku postępowania o nadanie stopnia naukowego doktora habilitowanego skala oscyluje od 100 do 250 punktów ${ }^{3}$. Szybko jednak, po analizie dokumentów zamieszczonych na stronach internetowych, okazuje się, że wymaganą liczbę punktów można zdobyć dzięki artykułom jedno- czy dwupunktowym. W ten sposób ujawnia się niejako główny mechanizm ne-

\footnotetext{
${ }^{3}$ Np. Uniwersytet Rolniczy w Krakowie w swoich wymaganiach z 7 li stopada $2014 \mathrm{r}$. doprecyzowuje szczegółowo zasady obowiazujace przy uzyskaniu stopnia naukowego doktora habilitowanego określając, iż wartość dorobku naukowego według punktacji MNiSW powinna wynosič co najmniej 250 pkt. Zob. Wymagania (3) 7.11.2014 r. ur.krakow. pl/zasoby/79/BRKNiWzG_2014_zasady.pdf.
}

gatywnych zachowań. Coraz powszechniejszą praktyką jest także tworzenie własnych, wewnętrznych rankingów naukowców, doktorantów czy studentów, którzy na podstawie liczby zdobytych punktów mają pierwszeństwo w otrzymywaniu nagród, stypendiów bądź innych formach promocji (np. wyjazdy na konferencje, szkolenia czy uczestnictwo w programach wymiany międzynarodowej). Nie dziwi zatem, że naukowcy zbierają, gdzie się da owe osławione ministerialne punkty, nie rozumiejąc nierzadko ich istoty, panicznie wręcz reagując na sugestię, że punkty te w prawdziwym świecie nauki nic nie znaczą.

Wszystko wskazuje na to, że tego typu praktyki będą jeszcze długo respektowane, gdyż w samym środowisku akademickim nie ma pomysłu na ich rozwiązanie, a różnice w poglądach na temat ewentualnych działań naprawczych są bardzo podzielone, przy czym linia podziału wydaje się przebiegać między reprezentantami nauk humanistycznych i społeczno-ekonomicznych a nauk ścisłych, medycznych przyrodniczych i technicznych. Przedstawiciele tej drugiej grupy postulują konieczność doprecyzowania i uszczegółowienia kryteriów ilościowych oceny dorobku naukowca, np. poprzez ustalenie minimalnego poziomu w postaci sumarycznego współczynnika wpływu Impact Factor (IF), liczby zdobytych punktów MNiSW czy indeksu Hirscha. Z kolei przedstawiciele nauk humanistycznych i społeczno-ekonomicznych uważają, że większy nacisk powinien być położony na wartość merytoryczną dorobku, a nie rangę czy punktację czasopisma, w którym opublikowano artykuł. Pamiętajmy, że w polskich realiach dochodzi jeszcze krytykowany od lat problem nierzetelności owej punktacji ${ }^{4}$ : obecne kryteria przyznawania punktów czasopismom na tzw. liście ministerialnej $\mathrm{B}^{5}$ są niemal zupełnie formalne (np. 30\% punktów można uzyskać za częstotliwość wydawania czasopisma i liczebność artykułów w nim publikowanych), nikt nie weryfikuje też prawdziwości danych zgłaszanych przez redakcje czasopism. Można zaryzykować opinię, że aktualna lista nie odzwierciedla faktycznego poziomu poszczególnych czasopism.

Drugą, zbliżoną i być może najważniejszą w przyjętej tu perspektywie przyczynę stanowi nieokiełznana ambicja i intencja bycia najlepszym

\footnotetext{
Zob. np. uwagi redaktorów czasopism naukowych, którzy zaniepokojeni likwidacją ministerialnej listy B czasopism postulują „odejście od wyłącznie formalnych kryteriów na rzecz ich połączenia z jakościową oceną ekspercką" oraz zwracają uwagę na „konieczność wypracowania dodatkowych, jakościowych kryteriów, które pozwoliłyby wyselekcjonować czasopisma o najwyższych standardach naukowych, wyłączając z parametryzacji te, które mają charakter popularny". Zob. List Redaktorów ogólnokrajowych czasopism naukowych z wykazu B Ministerstwa Nauki i Szkolnictwa Wyższego (2017). Forum Oświatowe, 30(2), 143-146.

Część B to tzw. lista krajowych czasopism naukowych, a więc tych których wydawca lub redakcja ma siedzibę w Polsce i działa zgodnie z ustawą z 26 stycznia 1984 r. Prawo prasowe, nieposiadających współczynnika wpływu Impact Factor (IF), którym przypisano określoną liczbe punktów za publikacje. Czasopisma te podzielono na trzy grupy nauk (TZ - techniczne, ścisłe, medyczne, przyrodnicze; S - społeczne; $\mathrm{H}$ - humanistyczne), które z uwagi na pewne odrębności zróżnicowano progami granicznymi w ocenie formalnej i bibliometrycznej. Obecnie czasopisma te moga mieć maksymalnie 15 pkt.
} 
w przeróżnych rankingach (wewnętrznych i zewnętrznych) wielu osób zarządzających poszczególnymi jednostkami. Mamy tu do czynienia $\mathrm{z}$ sytuacją chorej rywalizacji pomiędzy poszczególnymi instytucjami badawczymi, co jest niejako sprzeczne $\mathrm{z}$ ideą dobrych praktyk i rozwiązań w systemie szkolnictwa wyższego. Oczywiście sama rywalizacja jest bardzo potrzebna, niestety zbyt często towarzyszą jej naciski, niepożądane praktyki oraz zachęty do patologicznych zachowań.

W tej perspektywie warto też wspomnieć, że istnieje spora grupa naukowców, zwłaszcza tych ze starszego pokolenia, którzy nie tylko nie rozumieją do końca parametryzacyjnych zasad, ale też gubią się w nowych modelach upowszechniania i promocji nauki (np. otwarty dostęp do publikacji, nowe kanały i gatunki publikacji) w związku z czym są podatni na podejrzane oferty drapieżnych wydawców (ang. predatory journals publishers). Nieświadomi zagrożeń z jednej strony, a rozliczani z produktywności publikacyjnej i wartości wskaźników bibliometrycznych z drugiej, godzą się na niekorzystne oferty współpracy przekonani o słuszności takiego postępowania. Co gorsza w ten sposób dają młodszym adeptom nauki (doktorantom, młodym pracownikom nauki) znak, że takie postępowanie jest dopuszczalne, uznawalne i akceptowane w środowisku naukowym.

Są też i tacy naukowcy, którzy przejrzeli mechanizmy reprodukowania i uczestnictwa w grze parametrycznej i wiedzą, że bez pewnych zabiegów po prostu niemożliwe jest ich dalsze funkcjonowanie w życiu akademickim. Decydują się więc na przystąpienie do parametrycznej gry stając się bliskim negatywnego ideału „akademikiem przystosowanym", wpisanym w zasadę sterowalności, a więc takim, który ukierunkowuje własne działania na parametryczne cele pożądane nie tylko z perspektywy uczelnianej, ale także krajowej polityki naukowej.

\section{Iluzje działań - katalog niepożądanych czynności}

Dla współczesnego funkcjonowania uczelni parametryzacja ma znaczenie decydujące, gdyż jest jednocześnie systemem określającym praktyki uczelniane i ich percepcję, nie dziwi zatem, że te wpojone bardzo głęboko zasady konstrukcji rzeczywistości uczelnianej, strukturyzują przestrzeń, pozycję i relacje, które zajmuje dany naukowiec. Okazuje się, że system ten miewa też swoje kryzysy, które wynikają z jego właściwości strukturalnych, dzięki czemu możemy łatwo wskazać przykłady kilku niekorzystnych działań podejmowanych przez naukowców, zwłaszcza tych słabszych, którzy uwikłani w akademickie powinności (np. przymus okresowej rozliczalności) porzucają nierzadko naukowy obiektywizm i etyczne zasady decydując się na naganne zachowania, które w zdecydowanej mierze przypadków są negatywną konsekwencją stosowania ilościowego wskaźnika w wielu proce- sach podejmowania strategicznych decyzji w życiu akademickim.

Trudno nawet rozstrzygnąć, które z omówionych poniżej zachowań jest najgorsze. Nie ulega natomiast kwestii, że działanie polegające na wielokrotnym wykorzystywaniu tych samych wyników do tworzenia wielu publikacji (tzw. duplicate publications) jest bardzo powszechnym zjawiskiem. Podwójna lub nawet czasami wielokrotna publikacja, w której autor ponownie interpretuje, analizuje lub omawia wyniki swoich badań następuje wtedy, gdy badacz świadomie wykonuje jedno z trzech działań: a) wykorzystuje swój własny materiał wielokrotnie nie przyznając się do tego w odwołaniach źródłowych, b) przygotowuje kolejne artykuły korzystając z tych samych danych nie wspominając o tym w tekście, c) wysyłając te same artykuły, w tym samym czasie do różnych wydawców nie powiadamiając ich o tym. W ten sposób dochodzi nie tylko do zniekształcenia procesu metaanalizy, ale także do zaburzenia indeksów cytowań czy wpływów cytowań w bibliometrycznych wskaźnikach. Nierzadko kolejna praca jest znacząco podobna do opublikowanej już pracy tego samego autora, często bez podania źródła oraz bez uzyskania zgody pierwotnego właściciela praw autorskich, którym pozostaje wydawca. Bywa i tak, że autorzy zadają sobie pewien trud, aby ukryć duplikat, choć najczęściej ograniczają się do wprowadzenia nieznacznych różnic pomiędzy oryginałem a nowym tekstem, takich jak nadanie nowego tytułu lub zmodyfikowanie abstraktu, gdyż zestaw danych i ustalenia pozostają najczęściej bez zmian.

Tego typu postępowanie, choć nie ma znamion nieuprawnionego plagiatu czy naruszenia praw autorskich $^{6}$, jest postrzegane jako niewłaściwe i budzi wątpliwości wydawców, którzy starają się przed nim aktywnie bronić. Większość czołowych wydawnictw (jak np. Elsevier, Springer czy Nature) opracowało specjalne zasady przeciwko powielaniu publikacji opisujac $w$ swoich wytycznych redakcyjnych jak rozpoznać i unikać tego typu zachowań. Niestety nierzadko egzekwowanie tych zasad jest możliwe jedynie w przypadkach, w których istnieje znaczne duplikowanie danych lub partii tekstu. Bywa jednak i tak, że linia zależności czy podobieństw między publikacjami jest znana tylko autorowi i trudno redaktorom czy recenzentom, bez znajomości pewnych faktów, odkryć istniejące podobieństwa. Nie dziwi zatem coraz powszechniejsza praktyka, aby autorzy wraz z tekstem dostarczali wydruki wszystkich wcześniejszych artykułów, które mogą mieć znaczenie dla nadesłanej do publikacji pracy. Ostatecznie wiele jednak zależy od uczciwości autorów, którzy np. przez nieumiejętne powołanie się na wcześniej opublikowaną prace lub świadome pominięcie odwołań wprowadzają czytelników w błąd.

Nikt już chyba dzisiaj nie zaprzeczy, że chęć szybkiego publikowania i maksymalizacji liczby

\footnotetext{
${ }^{6}$ Kwestię ewentualnego naruszenia praw autorskich omawia szczegółowo J. Sieńczyłło-Chlabicz, J. Banasiuk (2012).
} 
artykułów towarzyszy wielu badaczom, którzy po pierwsze pragną zaistnieć w gronie specjalistów, a po drugie dążą do powiększenia swego dorobku naukowego (Habibzadeh, Winker, 2009). Z przeprowadzonych na początku XXI w. badań na Uniwersytecie Kalifornijskim w San Francisco wynika, że 75\% wydawców i 94\% autorów twierdzi, iż powtórna, zbyteczna publikacja (ang. redundant publication) jest głównie efektem presji uczelni wyższych oraz braku odpowiedniej reakcji ze strony wydawców, którzy nie podejmują skutecznych środków w celu zmniejszenia tego zjawiska i nie nakładają sankcji na autorów (Berlin 2009). W tym kontekście nie dziwi więc, że wielu naukowców decyduje się na wysłanie tego samego maszynopisu do kilku redakcji jednocześnie, oczywiście nie informując o tym fakcie redaktora czasopisma, tłumacząc to chęcią jak najszybszego dotarcia do czytelników. Niestety w ten sposób narażają się na możliwość duplikacji tekstu, co dzisiaj przy pośrednictwie internetu, wyszukiwania cyfrowego i indeksu cytowań szybko zostaje wykryte i zdemaskowane. Wszak już w 1969 r. Franz J. Ingelfinger, redaktor „The New England Journal of Medcine” jako pierwszy wydał wojnę autorom oznajmiając, iż nie przyjmie do publikacji tekstu rozpowszechnionego na łamach innego czasopisma (Toy, 2002). I choć jego zasada początkowo budziła kontrowersje dzisiaj większość prestiżowych wydawnictw wprowadziło reguły zabraniające tego typu praktyk. Pomocą w tym zakresie służyły takie organizacje, jak Committee on Publication Ethics (COPE), International Committee of Medical Journal Editors (ICMJE), World Association of Medical Editors (WAME) czy The European Associastion of Science Editors (EASE), które przygotowały odpowiednie wskazówki oraz procedury. Na szczęście zjawiska tego rodzaju są także demaskowane przez różnego rodzaju narzędzia, które pomagają w wykrywaniu tych samych publikacji ${ }^{7}$ (Errami M. i in., 2008).

Pozostaje tylko odpowiedź na pytanie czy ponowne opublikowanie artykułu stworzonego i wydanego wcześniej w innym czasopiśmie bądź monografii jest niemożliwe i zabronione? Nie, gdyż nierzadko ponowne wydanie pełni funkcję informacyjną, dostarcza ważne idee i koncepcje nowym czytelnikom, ale od zduplikowanej publikacji różni się tym, że jest to wyraźnie i poprawnie oznaczone co pozwala na rozpoznanie w analizie cytowań. $\mathrm{Z}$ podobną sytuacją mamy także do czynienia, gdy autor pisze artykuł na ten sam temat - jest wówczas wielce prawdopodobne, że część tekstu, twierdzeń, a nawet tez będzie powtórzeniem wcześniejszych tekstów, ważne jednak, aby w zakresie zawartości merytorycznej tekstu wyraźnie odróżnić swoje oryginalne wyniki i hipotezy od wcześniejszych publikacji oraz podać wszystkie źródła (Sieńczyło -Chlabicz, Banasiuk, 2012).

Zob. np. eTBLAST, automatyczne narzędzie do porównywania cytatów czy Déjà vu otwarta baza cy towań. Narzędzia te są bezpłatne, dostępne pod adresem http://invention.swmed.edu/ oraz http://spore.swmed. edu/dejavu.
Bardzo podobnym zjawiskiem jest tzw. salami slicing, czyli praktyka dzielenia ważnych wyników badań naukowych na mniejsze części, z których każda jest publikowana jako osobny artykuł. W obliczu parametryzacyjnych wyliczeń pokusa publikacji jak największej liczby artykułów na podstawie tych samych danych jest duża. Absurdalnym przykładem takiej praktyki jest np. przypadek irańskiego naukowca, który w czasopiśmie „Archives of Iranian Medicine” opublikował zestaw 33 artykułów na temat jednego badania (www.blogs.discovermagazine.com/neuroskeptic/2018/03/03/salami-slicing-32-papers). Tego typu praktyka fragmentacji pojedynczych badań na możliwie jak największą liczbę publikacji jest nie tylko poważnym naruszeniem etyki autorskiej, ale i poważnym problemem organizacyjnym dla redakcji czasopism oraz recenzentów - autorzy w nieuprawniony sposób wykorzystują moce przerobowe redakcji oraz zajmują i tak ograniczoną przestrzeń publikacyjną czasopism. Jest to także duża niedogodność dla odbiorcy, gdyż jest on zmuszony do zakupu/prenumeraty kolejnych numerów danego czasopisma, aby móc poznać i zanalizować pełne wyniki badań.

W granicach wyznaczonych przez etyczne reguły pisania i publikowania nie mieszczą się także dwa kolejne zjawiska: ghost authors, czyli niewskazywanie rzeczywistych autorów przyczyniających się do powstania publikacji oraz honorary authorship, czyli praktyka polegająca na dodawaniu do listy autorów renomowanego nazwiska badacza, który nie wniósł żadnego wkładu w powstanie tekstu. O skali tego problemu możemy się przekonać m.in. z licznych publikacji Marka Wrońskiego, który na łamach „Forum Akademickiego” w rubryce „Z archiwum nierzetelności naukowej” opisuje liczne przypadki nieuczciwości publikacyjnej odnośnie autorstwa tekstu. Znaczna część nieporozumień w tym zakresie wynika zapewne stąd, iż tak naprawdę nieliczni zdaja sobie sprawę z faktu, iż „współpraca w tworzeniu dzieła naukowego nie zawsze oznacza jego współautorstwo, współautorstwo zaś może oznaczać zarówno znaczny, jak i stosunkowo niewielki wkład twórczy" (Zespół do Spraw Dobrych Praktyk Akademickich, 2011, s. 140).

Terminem ghost authors określa się także zawodowych pisarzy, którzy dzięki swej eksperckiej wiedzy na płatne zlecenie firm (głównie farmaceutycznych, przemysłowych) podejmują badania, tworzą i analizują dane. Później do pracy przystępują naukowcy wyposażeni w odpowiednie kompetencje, którzy interpretując otrzymane dane tworzą różnorodne teksty naukowe kreując wiedzę na określony temat. W ten sposób ukrywa się zaangażowanie i poparcie dla pewnych badań, zachowując pozorny obiektywizm artykułu przy jednoczesnym zachowaniu pełnej kontroli nad jego treścią (www. aje.com/en/arc/ghost-authorship). Bywa i tak, że naukowcy zatrudniają pomocników, którzy np. na ich zlecenie gromadzą, analizują dane lub wykonują inne, potencjalnie ważne czynności w procesie ba- 
dawczym, ale nie informują o tym swoich czytelników. Rzadko, niemniej zdarza się, że ghost authors bywa wykorzystywany do takich czynności, jak redakcja czy tłumaczenie tekstu, tłumaczenie obcojęzycznej literatury przedmiotu czy redukowanie barier w publikacji artykułu (słabe umiejętności pisarskie, ograniczony czas lub brak znajomości wymagań danego czasopisma). Ciekawych informacji w tym zakresie dostarczają badania J. Wislara i in. (2011), którzy po zbadaniu 896 artykułów badawczych, przeglądowych i redakcyjnych opublikowanych w sześciu czasopismach medycznych o wysokim wpływie (wskaźniku IF) wydanych w roku 2008 stwierdzili, że aż 7,9\% artykułów powstało przy udziale ghost authors. Znacznie gorzej wygląda to w przypadku tzw. honorowego autorstwa (honorary authorship), czyli praktyce polegającej na dodawaniu renomowanego nazwiska badacza akademickiego w celu zwiększenia wiarygodności podawanych wniosków czy tez, pomimo niewielkiego, lub nawet żadnego rzeczywistego zaangażowania uczonego. Według wspomnianych wcześniej badań, aż 17,6\% artykułów miało tzw. autorów honorowych, którzy najczęściej występowali w oryginalnych raportach z badań (25\%), w recenzjach (15\%) i w artykułach redakcyjnych $(11,2 \%)$ (Wislar i in., 2011). Dla tego typu działań najbardziej charakterystyczną postawą jest dopisywanie do listy autorów tych osób, które nie wniosły żadnego wkładu $\mathrm{w}$ badania czy pisanie, ale $\mathrm{z}$ uwagi na swoją pozycję naukową i zawodową uwiarygadniają niejako cały tekst. Wpływowy i znany naukowiec dopisany jako współautor niejako uprawomocnia, legitymizuje wywód, wzmacnia także pozycję głównego autora. Jest to dość powszechne zjawisko zwłaszcza w przypadku debiutantów, kiedy np. promotor pracy doktorskiej dopisywany jest jako autor do pierwszych artykułów swojego doktoranta. Warto dodać, że na niektórych uczelniach czy wydziałach taka praktyka jest nie tylko oczekiwana, ale nawet uznawana jako obowiązująca i młodym adeptom nauki nawet nie przychodzi do głowy, aby z tym zjawiskiem walczyć. W praktyce zatem coraz więcej wydawców czasopism stara się obecnie zadbać o rzeczywiste uznanie wymagając np. określenia indywidualnego wkładu poszczególnych autorów czy wskazania jaka część tekstu została przygotowana przez profesjonalistów z branży nie wymienionych jako autorzy (zob. www.springer.com/gp/authors-editors/ authorandreviewertutorials/biomed-central-editor-tutorials/publication-and-research-ethics-andmisconduct/authorship-issues-guest-gift-or-ghost). Paradoks zjawiska polega tylko na tym, że w zasadzie cała ta dbałość o uznanie autorstwa ma charakter pozorny. Wzmożone wysiłki ze strony czasopism naukowych niewiele jednak dadzą skoro indywidualni autorzy czy instytucje akademickie nie zmienią swego dotychczasowego stosunku do zagadnienia rzetelnej atrybucji autorstwa publikacji naukowej.

Kolejnym działaniem, które warto poddać analizie są nieformalne porozumienia prowadzące do zwiększenia liczby cytowań. W obecnej aurze dominacji wskaźników liczbowych niewykluczone i wielce prawdopodobne jest uruchomienie okołouczelnianej machiny wzajemnych cytowań. Naukowcy skazani na wypracowanie odpowiedniej liczby wskaźników, od których nierzadko zależy ich pozycja na uczelni, w świadomy sposób mogą zawierać porozumienia odnośnie wzajemnych cytowań. Łatwo sobie wyobrazić sytuację, gdy współpracujące ze sobą zespoły lub grupy badaczy działające $w$ podobnych dziedzinach, zawierają mniej lub bardziej formalne porozumienia prowadzące w ogólnym rozrachunku do powiększenia liczby cytowań. Wyraźna w takim postępowaniu jest kwestia tzw. solidarności grupowej polegającej na podejmowaniu szeregu wzajemnych działań różnorakiej pomocy lub też systematycznego pomijania i zwalczania naukowców spoza tejże grupy. Wszak tajemnicą poliszynela jest w zasadzie powszechna w polskim środowisku naukowym niezwykle zaangażowana postawa zwalczania antagonistycznych zespołów czy badaczy. Rodzące się opozycje i podziały mogą prowadzić do zawierania sojuszy polegających na wzajemnym cytowaniu popleczników i świadomym pomijaniu naukowców uważanych za wrogich. I choć takie praktyki bardzo trudno ujawnić, są powody do przypuszczeń, że taki proceder powoli się rozwija, gdyż „walka o maksymalną cytowalność jest niewysychającym źródłem korupcji i patologii" (Walicki, 2011). Zwolennicy tego typu praktyk zdają się udawać, że nie wiedzą iż tego typu postępowanie prowadzi w oczywisty sposób do fałszowania wyników parametrycznych.

Lektura wielu prac (m.in. Elsaie, Kammer, 2009; van Diest, Holzel, Burnett, Crockre, 2001), a także doświadczenie redaktorskie (moje przynajmniej) przekonuje, że kolejnym zjawiskiem wielokrotnie analizowanym przez znawców jest tzw. impaktoza, która została zdefiniowana jako usilne dążenie do publikowania wyników badań tylko w czasopismach o najwyższej wartości wskaźnika Impact Factor (IF) wyliczanego przez firmę Thomson Reuters, który jest obecnie nie tylko bezpośrednią miarą jakości czasopisma i poziomu jaki reprezentuje opublikowany artykuł, ale także pośrednią oceną wartości autora tekstu. Stworzony przez Eugene Garfielda i Irvina Shera w latach 60. XX w. współczynnik wpływu czasopisma dla Science Citation Index (SCI) stał się obecnie przedmiotem wielu negatywnych opinii i kontrowersji. Pomimo kontrowersji IF jest niezwykle pożądany przez naukowców, którzy pragną tych wymarzonych „impaktów” i nierzadko wszystkie swoje naukowe działania ukierunkowują na ich zdobycie. Zdarza się, że na uczelnianych korytarzach czy w konferencyjnych kuluarach słychać tylko rozmowy o tym, ile kto ma „sumarycznych impaktów”8. Można nawet mówić

${ }^{3}$ Sytuacja chyba w najbliższym czasie nie ulegnie zmianie skoro w rozporządzeniu MNiSW w sprawie kryteriów oceny osiągnięć osoby ubiegającej się o nadanie stopnia doktora habilitowanego $\mathrm{w}$ dziale odnośnie oceny w zakresie osiagnnięć naukowo-badawczych mówi się wprost o „sumarycznym impact factor publikacji naukowych” (§ 4, pkt 
o pewnej giełdzie naukowców i opozycji pomiędzy tymi, którzy „impakty” posiadają, a tymi którzy ich jeszcze nie zdobyli, z których ci pierwsi nierzadko dystansują się od tych nieposiadających i zamykają w swoim kręgu, drudzy zaś marząc o tych magicznych wskaźnikach przypominają o szarej rzeczywistości egzystencjalnej nauki.

Krytyka impaktozy ogranicza się w zasadzie do przypominania o tym, że jest to niedoskonałe narzędzie porównywania jakości pracy poszczególnych naukowców, naznaczone brakiem bezstronności oraz sporą redukcyjnością sprowadzającą wszystko do wskaźników ilościowych. Te wady impaktozy są - jak przekonuje Kulczycki - zasadniczo zbieżne z punktozą. Nie jest to podobieństwo przypadkowe, gdyż oba zjawiska „odnoszą się do zjawiska dostosowywania przez naukowców swoich praktyk publikacyjnych do ilościowo wyrażonej normy dotyczącej jakości” (Kulczycki, 2017, s. 68). Niemniej jednak punktoza ma pewne narodowe odrębności i stwarza fikcyjną polską rzeczywistość akademicką, kiedy to pod pozorem symulowania badań naukowcy tak definiują swoje cele badawcze „aby ich wyniki były publikowane bez znaczącego wysiłku ze strony naukowca" (Kulczycki, 2017, s. 68). Rzecz w tym, że punktoza jest klasycznym przykładem gry podejmowanej przez słabych akademików, którzy są świadomi faktu, że obecny system nauki i jego mechanizmy (m.in. zasady ewaluacji nauki, nadmierne ukierunkowanie na wskaźniki ilościowe i osłabienie orientacji badawczej) pozwalają im na utrzymanie się w akademickim świecie, dopóki publikują „cokolwiek” w czasopismach legitymizowanych przez system, czyli tych, które mieszczą się na ministerialnej liście czasopism punktowanych. Zrodzone wśród akademików przeświadczenie niejako utrwala negatywny stan polegający na tym, że nie dążą oni do publikowania swoich wyników badań w najlepszych czasopismach naukowych, dzięki czemu nie tylko nie istnieją w najważniejszym kanale komunikacji naukowej, nie upowszechniają wiedzy, ale również nie nadają odpowiedniej rangi publikowanym treściom decydując się na publikowanie wielu (często nisko punktowanych) artykułów w słabo uznawanych przez wspólnotę akademicką czasopismach. Bywa i tak, że pręgierz parametryzacyjny może do tego stopnia wpłynąć na działalność naukowców, że zaczną oni korzystać z wątpliwych przede wszystkim etycznie ofert drapieżnych wydawców, czyli tych którzy nie respektują podstawowych zasad i standardów naukowego publikowania (m.in. odpowiedni proces recenzyjny, a potem redakcyjny), publikują w zasadzie wszystko i to najczęściej w modelu otwartego dostępu, co niejako ma uzasadniać ponoszenie opłat przez autora. Pierwszymi ofiarami drapieżnych wydawców są oczy wiście sami autorzy: pomimo podjętych wysiłków oraz zainwestowanych nierzadko znacznych środków finansowych ich prace nie zaistnieją w naukowym obiegu.

\footnotetext{
3) (t.j. Dz.U. 2011, nr 196, poz. 1165)
}

Jednakże szanse na pojawienie się czegoś, co mogłoby uleczyć tę sytuację, są jak na razie niewielkie. Tak przynajmniej zdaje się argumentować Dariusz Jemielniak w swoim komentarzu na temat rankingu wydawców (www.ekulczycki.pl/warsztat_badacza/wykaz-wydawcow-naukowych-a-model-biznesowy). Punktem wyjścia zamieszczonych tam uwag jest polemiczne nawiązanie do tezy, że samo stworzenie Wykazu Wydawców Uczelnianych (co zakłada nowy projekt ustawy) nie rozwiaże problemu nierzetelnych, nie dbających o jakość wydawnictw nastawionych na model biznesowy, w których można wydrukować w zasadzie wszystko głównie z uwagi na istniejący zaburzony system dotacji na wydanie prac i nieuczciwy proces recenzyjny. Jemielniak sprzeciwia się stanowczo modelowi Vanity Pres ${ }^{9}$, postulując jego porzucenie. Jego zdaniem w polskich wydawnictwach „To autor praktycznie decyduje, który wydawca dostanie pieniądze. W rezultacie, proces recenzowania polskich wydawców robi się zazwyczaj grzecznościowy: sam autor miewa wpływ na to, kto napisze recenzje, nie są one anonimowe, a ich celem nie jest znaczące przeedytowanie i zmiany w manuskrypcie, lecz po prostu decyzja, czy wydać, czy nie" (www.ekulczycki.pl/warsztat_badacza/wykaz-wydawcow-naukowych-a-model-biznesowy). Radykalna krytyka tego systemu, któremu zarzuca się komercjalizm, nieuczciwość, nierzetelność, nadużycia oraz niskie standardy odnośnie opracowania publikacji nie zniechęca niektórych przed korzystaniem z ich usług. Jedni czynią to z niewiedzy - nie potrafią odróżnić fikcji i pozorowania od właściwych działań edytorskich, inni zaś z premedytacją poświęcaja swój czas i pieniądze na poszukiwanie takich wydawców, którzy pozwolą im szybko wydać pracę (rekordziści proponują wydanie monografii w 14 dni!) i zdobyć upragnione punkty. Zresztą sami wydawcy zdają się ten proces znacznie ułatwiać przesyłając gotowe oferty na skrzynki emailowe naukowców. Prezentują tam oczywiście rozwiązania jak najkorzystniejsze z punktu widzenia procesu parametryzacyjnego: wydanie monografii naukowej, której liczba autorów nie będzie przekraczać trzech, a na dodatek każdy z nich będzie pochodził z innej jednostki naukowej i przygotuje swoją dwuarkuszową część nie oznaczoną i nie wyodrębnioną z całości co pozwoli każdemu z autorów otrzymać maksymalną liczbę 25 pkt. Jeszcze korzystniejsze oferty przysyłają wydawcy obsługujący różnorakie konferencje proponujący opublikowanie nierzadko, aż trzech pseudoprac: streszczenia w materiałach pokonferencyjnych i dwóch artykułów w dodatko-

\footnotetext{
Jest to jedna z odmian tzw. samopublikowania (ang. self-publishing) kiedy to nakładem własnym autora wydawana jest publikacja. Vanity Press oferuje profesjonalne przygotowanie pracy (w tym redakcję, korektę druki oprawę) każdemu, kto jest gotowy za to zapłacić więcej niż wynoszą koszty przygotowania wraz z kosztami promocji i dystrybucji. Mówiąc w największym skrócie: realizowana przez te wydawnictwa taktyka ma niewiele wspólnego z publikowaniem naukowym, gdyz zgłaszane teksty nie przechodzą wersy fikacji jakościowej (redakcyjnej i recenzyjnej), często też nie spełniają określonych kryteriów naukowości i oryginalności, nierzadko świadczą o niskich kompetencjach badawczych bądź umiejętności pisania naukowego.
} 
wych monografiach towarzyszących konferencji. SPAM z propozycjami publikowania u drapieżnych wydawców jest niemalże powszechny i nawet rozporządzenie o ochronie danych osobowych nie zmniejszyło tego procederu. Bezceremonialne, odważne i jakże „pragmatyczne” oferty są w zasadzie codziennością każdego naukowca, który w dobrej wierze udostępnia na stronie internetowej swój adres emailowy. Bywa i tak, że doprowadzony do ostateczności naukowiec może postąpić niczym Peter Vamplew ${ }^{10}$, ale jak widać z jego przykładu nie rozwiązuje to sytuacji.

Otrzymywane propozycje dotyczą głównie publikacji artykułów naukowych w tzw. drapieżnych czasopismach, których nazwy są często łudząco podobne do prestiżowych czasopism. Drapieżne czasopisma to kolejny przykład złych praktyk w komunikacji naukowej. Wydawcy takich czasopism publikują wszystkie otrzymane artykuły, pozorując jedynie system oceny recenzenckiej i standardy wydawnicze, a jedynym warunkiem jest wniesienie odpowiedniej, nierzadko wysokiej, opłaty. Niestety niektórzy naukowcy zaskoczeni, a przy tym uradowani propozycją publikacji w międzynarodowym czasopiśmie z nierzadko tajemniczym „uniwersalnym Impact Factor" nie dostrzegają zagrożeń, zwłaszcza, że niestety część z tych czasopism jest indeksowana na ministerialnej liście B czasopism (Kulczycki, 2014), co niejako je uwiarygadnia. Nie dziwi więc, że chętnie przystają na współpracę nie wiedząc o tym, że publikacja w takim czasopiśmie jest stratą czasu i pieniędzy, gdyż nie są one indeksowane przez międzynarodowe bazy typu Scopus czy Web of Science ${ }^{11}$, a w związku z tym nie są wykorzystywane i uznawane przez międzynarodową społeczność naukową. Brak rozeznania na rynku wydawniczym oraz słaba znajomość reguł wydawniczych oraz wskaźników i zasad bibliometrycznych sprawia, że tego typu wydawcy wciąż istnieją na rynku, pokładając wiarę $\mathrm{w}$ to, że naukowcy nie poznają się na ich nieuczciwej symulacji. Rzecz w tym, iż świadomość naukowców jak rozpoznać drapieżne czasopisma jest dość niska. Dlatego z zadowoleniem należy przyjąć każdą formę popularyzacji wiedzy na ten temat. W tym miejscu warto przywołać empiryczny eksperyment obnażający dogłębnie metody i sposób działania drapieżnych wydawców, na który w myśl posłannictwa kultywowania wiedzy o tych drapieżnych praktykach zdecydowała się polska grupa naukowców. Tworząc fikcyjną naukowczynię Annę O. Szust próbowano zdobyć posa-

\footnotetext{
${ }^{10}$ Zdenerwowany rumuński badacz znudzony wciąż powtarzającymi się propozycjami odpisał na jedną z nich używając słów „Get me off Your Fucking Mailing List”. Jakże się zdziwił, gdy ten jego 'tekst' został zaakceptowany do druku przez redakcje periodyku „International Journal of Advanced Computer Technology". 0 przypadku tym napisał bibliotekarz akademicki Jeffrey Beall, który na swoim blogu Scholarly Open Access prowadził od $2012 \mathrm{r}$. listę drapieżnych wydawców. Na początku maja tego roku blog wraz z listą został zamknięty, najprawdopodobniej z powodu nacisków politycznych i grożących pozwów sądowych ze strony wydawnictwa Frontiers lub OMICS Publishing Grioup.

${ }^{11}$ Aby czasopisma zostały przyjęte do powyższych baz są skrupulatnie sprawdzane pod kątem spełnienia wymogów technicznych oraz jako-
}

dę redaktora czasopisma naukowego. $\mathrm{W}$ tym celu wysłano aplikację Szust do 360 czasopism, po 120 z każdego z trzech znanych katalogów: JCR (Journal Citation Reports), DOAJ (czasopisma zawarte w Katalogu czasopism o otwartym dostępie) oraz z tzw. listy Beale'a (potencjalne lub prawdopodobne drapieżne wydawnictwo i czasopismo o otwartym dostępie). Jak się okazało w wielu przypadkach pozytywna odpowiedź dotarła w ciągu kilku dni od złożenia wniosku, a czasami nawet w ciągu kilku godzin. Cztery tytuły natychmiast powołały Szust na redaktora naczelnego. Co ważne żadne czasopismo z listy JCR nie zaakceptowało Szust, 8 z listy DOAJ wyznaczyło ją na redaktora, zaś z ostatniej listy było to aż 40 tytułów (Sorokowski i in., 2017). Eksperyment ten tylko wskazuje na skalę problemu „Wielkich Nadużyć” i niejako zmusza do podjęcia stanowczych działań polegających na dostarczeniu narzędzi i teoretycznej wiedzy w sprawie umiejętności rozpoznawania oszustów wydawniczych (Beall, 2012). Zwłaszcza, że wiele drapieżnych wydawnictw prowadzi swoją działalność w bardzo wyrafinowany sposób (np. strona internetowa czy tytuł czasopisma są zbieżne $\mathrm{z}$ flagowym tytułem $\mathrm{w}$ tej dziedzinie) i nawet doświadczeni naukowcy mogą ulec oszustwu stając się w łatwy sposób członkiem redakcji lub drukując artykuły po uiszczeniu wysokich opłat za publikację (zob. Bartholomew, 2014).

Przy okazji procedur wydawniczych, jak i wszelkich sposobów ich niewłaściwego obchodzenia warto jeszcze wspomnieć o tzw. drapieżnych konferencjach. Wszak „wobec inflacji konferencji, których w każdej niemal dziedzinie odbywa się wiele każdego roku, nie jest łatwo odróżnić konferencje o wysokim poziomie i surowej selekcji referatów, nawet konferencje bardzo elitarne, od innych, które zbierają wszystkie nadesłane prace, a jednym z ich celów jest zebranie pieniędzy z wpisowego" (Brandt, 2011, s. 137). Znamy wiele takich przykładów kiedy podważa się wszelkie granice naukowości i uczciwości badawczej. Najpospolitszym obecnie przewinieniem jest profesjonalne fabrykowanie pseudonaukowych konferencji, które wymykają się wszelkim zasadom. Wydaje się, że wszelkie granice przestały już działać: ogłasza się umowne, słabo sproblematyzowane spotkania naukowe (najczęściej interdyscyplinarne), zwykle w jakimś atrakcyjnym turystycznie miejscu, których jedynym celem jest tak naprawdę wycieczka krajoznawcza, spotkanie towarzyskie oraz opublikowanie jak największej ilości tekstów w zbiorczej monografii przed- i pokonferencyjnej. Można to powiedzieć jeszcze inaczej: naukowcy oraz organizatorzy umawiaja się na wspólną grę pozorów za odpowiednia opłatę. Chodzi zatem o to, aby akademik powrócił na uczelnię zadowolony, z odpowiednim certyfikatem uczestnictwa w międzynarodowej lub ogólnopolskiej konferencji i zagwarantowaną publikacją artykułu. Opłacalność takiej działalności musi być znaczna, skoro są i tacy organizatorzy, którzy ten 
typ działalności uznają za wiodący i wciąż rozwijają usługi towarzyszące wydarzeniu, zapewniając sobie liczne grono uczestników w każdej kolejnej edycji. Takie postępowanie sprawia, że niektórzy naukowcy powzięli awersję do konferencyjnych wyjazdów lub biorą $\mathrm{w}$ nich udział $\mathrm{z}$ wewnętrznym niesmakiem.

Wszystkie wskazane w tej części artykułu zjawiska mocno problematyzują kwestie oceny i porównań naukowców. Dlatego też eksperci przygotowujący zasady ewaluacji oraz oceny muszą „pamiętać o możliwych negatywnych skutkach takiego zliczania [...] aby je ograniczyć lub przynajmniej świadomie kontrolować" (Brandt, 2011, s. 136). Z dzisiejszej perspektywy widać bardzo dobrze, że wiele trzeba zrobić, aby poprawić i ujednolicić zasady, procedury i kryteria stosowane w ewaluacji, tak aby społeczność akademicka mogła pozbyć się słabych naukowców wykorzystujących różnorodne strategie przetrwania w środowisku naukowym i skoncentrować się na działalności badawczej i kształceniu, do których jest dobrze przygotowana.

\section{Co nas czeka?}

Procedowana właśnie ustawa ${ }^{12}$ zakłada wprowadzenie rewolucyjnych zmian w przyszłym systemie ewaluacji, który ma być sprawiedliwszy i bardziej miarodajny, głównie z powodu uwzględnienia specyfiki poszczególnych nauk i dziedzin. Wydaje się, iż nareszcie dostrzeżono, że obecnie mamy do czynienia z tzw. „WieloNaukami - odmiennymi, niekiedy przeciwstawnymi, sposobami badań, publikowania i komunikowania, które nie składają się na Naukę, lecz na wiele nauk" (Kulczycki, Drabek, Rozkosz, 2015, s. 54). I choć nowa ewaluacja zostanie przeprowadzona dopiero w $2021 \mathrm{r}^{13}$ przyjrzyjmy się już dzisiaj tym zmianom, które mają zapobiec zwłaszcza niekorzystnym praktykom publikacyjnym i sprawić, że trzy najbardziej problematyczne punkty oceny (artykułów, książek i podział punktów za publikacje) zostaną zniwelowane lub udoskonalone:

- postulowany model będzie uwzględniał odmienne praktyki publikacyjne i wzorce cytowań na poziomie dziedzin i poszczególnych dyscyplin - ta zmiana to niewątpliwy ukłon w stronę nauk humanistycznych, które przez ostatnie lata były niedocenione w systemie oceny czasopism - najlepszy nawet artykuł z zakresu np. historii nie otrzymywał tylu punktów co np. podobny tekst z zakresu fizyki czy medycyny;

- przywrócona zostanie ranga monografiom, które przez ostatnie lata były zdeprecjonowa-

\footnotetext{
${ }^{12}$ Piszę te słowa w czerwcu 2018 r. kiedy to komisja sejmowa zdecydowaną przewagą głosów przyjęła projekt ustawy o szkolnictwie wyższym i nauce zwany Konstytucja dla Nauki lub Ustawa 2.0 przygotowany przez resort nauki kierowany przez wicepremiera Jarosława Gowina. 4 lipca 2018 r. projekt zyskał poparcie polskiego parlamentu. 2 sierpnia ustawa została podpisana przez prezydenta RP, a zatem w życie wejdzie 1 października $2018 \mathrm{r}$.
}

${ }^{13}$ Obejmując okres 2017-2020. $n \mathrm{e}^{14}$, ale $\mathrm{w}$ ich ocenie nie będą już uwzględniane parametry formalne ${ }^{15}$, ile ich jakość będzie oceniana przez ekspertów z Komisji Ewaluacji Nauki;

- wprowadzony zostanie istotny ogranicznik w postaci limitu zgłaszanych do ewaluacji prac: każdy naukowiec będzie mógł zgłosić nie więcej niż cztery swoje najwybitniejsze osiągnięcia z okresu minionych czterech lat ${ }^{16}$;

- zacznie obowiązywać, opracowany we współpracy z Biblioteką Narodową, Wykaz Wydawnictw Naukowych, których publikacje będą wyżej punktowane. Na wykazie tym znajda się zarówno wydawnictwa zagraniczne, jak i polskie, które przestrzegają zasad Komitetu do spraw Etyki Publikacji (COPE). Wykaz ten zostanie opublikowany po wejściu w życie Ustawy 2.0, usuwając z rynku drapieżne, pseudonaukowe, wydawnictwa, które działaja w systemie Vanity Press - ich jedynym celem jest drukowanie publikacji spełniających wymogi formalne parametryzacji, a nie wydawanie publikacji naukowych zgodnie z zasadami edytorstwa naukowego. W tym przypadku ma działać tzw. zasada dziedziczenia prestiżu znana m.in. w Norwegii, Finlandii czy Hiszpanii.

- zostanie opracowany nowy Wykaz Czasopism Naukowych ${ }^{17}$ respektujących kanony rzetelności naukowej, oparty na wiodących międzynarodowych bazach bibliograficznych. Z kolei dla ok. 500 czasopism (głównie z zakresu nauk humanistycznych i społecznych) zostanie uruchomiony program „Wsparcie dla czasopism naukowych", w ramach którego redakcje będą mogły podjąć starania o środki na wdrożenie najlepszych rozwiązań niezbędnych we współczesnej komunikacji naukowej (np. systemy zarządzania pracą wydawniczą, cyfrowe identyfikatory publikacji czy systemy antyplagiatowe), co ułatwi im aplikowanie o wpis do międzynarodowych baz. Wykaz ten zostanie opublikowany po wejściu w życie ustawy,

\footnotetext{
${ }^{14} \mathrm{~W}$ poprzednich parametryzacjach zdarzało się i tak, że monografie były punktowane znacznie niżej od artykułów. Zdawano się przy tym zapominać, że monografie, rozdziały czy redakcje są fundamentalnym sposobem komunikowania się w wielu dyscyplinach

${ }^{15}$ Takich jak np. liczba arkuszy wydawniczych. Zob. § 11.1 Rozporządzenia Ministra Nauki i Szkolnictwa Wyższego z dnia 12 grudnia 2016 r. w sprawie przyznawania kategorii naukowej jednostkom naukowym i uczelniom, w których zgodnie z ich statutami nie wyodrębniono podstawowych jednostek organizacyjnych (Dz.U. 2016, poz. 2154)

${ }^{16}$ Limit ten ma nas ustrzec przed zjawiskiem punktozy, która sprawiła, że w kategoryzacji jednostek naukowych w 2017 r. do oceny za cztery lata zostało zgłoszonych 560000 publikacji. Rekordzista zgłosił w procesie ewaluacji aż 53 monografie z zakresu językoznawstwa (https:// www.nauka.gov.pl/aktualnosci-ministerstwo/czy-konstytucja-dla -nauki-zagraza-humanistom.html). W poprzedniej ewaluacji (2013 r.) zgłoszono 184456 publikacji (Kulczycki i in. 2015).

${ }^{17}$ Ma to zerwać z niechlubną praktyka powoływania - nierzadko przy ogromnym nakładzie pracy i pieniędzy - fikcyjnych, tymczasowych periodyków, które wprowadzano na tzw. listę B umożliwiając łatwe zdobywanie punktów za artykuły. W ten sposób w ciagu trzech lat zostało dodanych blisko sześćset nowych czasopism naukowych. Tymczasem jak wynika z raportu „Analiza opóźnień wydawniczych polskich czasopism naukowych" spośród 2356 czasopism naukowych 13\% miało opóźnienia odnoszące się do 2015 roku, a 63\% do roku 2016 (Drabek, Rozkosz i Kulczycki 2017).
} 
a jego kolejne wersje będą się ukazywały na początku kolejnych lat, tak aby punktacja była znana z góry.

\section{Zakończenie}

Czy opisane w ustawie działania uchronia nas naukowców przed zagrożeniami polskiego systemu oceny badań i nauki? Czy przestaną istnieć zniekształcone, w niektórych wypadkach wypaczone zasady oceny dorobku jednostek naukowych? Czy zanikną niekorzystne praktyki akademickie stawiające na ilość, a nie jakość polegające na tworzeniu sztucznych i dyskusyjnych tworów spełniających wymogi parametryzacji? Naiwnością byłoby stwierdzić, że tak na pewno się stanie. Na to pytanie dzisiaj nikt nie zna niestety odpowiedzi. Ważne, żebyśmy mieli jednak świadomość, iż proponowana i dyskutowana reforma będzie miała długofalowe konsekwencje, które niestety poznamy ex post. Jest jednak szansa na to, że wreszcie nastąpi prawdziwa modyfikacja dotychczasowych reguł, przejdziemy z ilości na jakość, zanikną niekorzystne praktyki akademickie, a naukowiec wreszcie będzie mógł się skupić na Nauce. Aby tak się jednak stało trzeba nie tylko rozpoznać specyfikę tych nieprawidłowych taktyk i ich nieprawdopodobnej skuteczności, ile prowadzić bezustanny dyskurs na ich temat, tak aby następne pokolenie młodych naukowców, uświadomione przez swoich mentorów konsekwentnie powielały tylko właściwe przykłady i idee. Rzecz bowiem nie w ustanowieniu bardziej wyrafinowanych metod oceny wartości naukowej badacza, ile w świadomości zalet uczciwego postępowania naukotwórczego.

\section{Literatura:}

1. Bartholomew, R.E. (2014). Science for sale: the rise of predatory journals. Journal of the Royal Society of Medicine, 107(10), 384-385. https://doi.org/10.1177/0141076814548526

2. Beall, J. (2012). Predatory publishers are corrupting open access. Nature, 489(7415), 179. https://doi. org $/ 10.1038 / 489179 a$

3. Berlin, L. (2009). Plagiarism, salami slicing, and Lobachevsky. Skeletal Radiology, 38(1), 1-4. https://doi. org/10.1007/s00256-008-0599-0

4. Brandt, A.M. (2011). O parametryzacji ocen w nauce w Polsce. Nauka, 3, 135-144.

5. Brzeziński, J.M. (2016). Przeciwko depersonalizacji i nadmiernej standaryzacji procesu ewaluacji w nauce. Zagadnienia Naukoznawstwa, 1(52), 127-138.

6. Diest, P.J., van Holzel, H., Burnett, D., Crocker, J. (2001). Impactitis: New cures for an old disease. Journal of Clinical Pathology, 54(11), 817-819. https://doi.org/10.1136/jcp.54.11.817

7. Elsaie, M., Kammer, J. (2009). Impactitis: The impact factor myth syndrome. Indian Journal of Dermatology, 54(1), 83-86. https://doi.org/10.4103/0019-5154.48998

8. Errami, M., Hicks, J.M., Fisher, W., Trusty, D., WrenTara, J.D., Long, C., Garner, H.R. (2008). Déjà vu - a study of duplicate citations in Medline. Bioinformatics, 24(2), 243-249. https://doi.org/10.1093/bioinformatics/btm574

9. Habibzadeh, F., Winker, M.A. (2009). Duplicate publication and plagiarism: causes and cures. Notfall Rettungsmed, 12, 415-418. https://doi.org/10.1007/s10049-009-1229-7

10. Kulczycki, E. (2014). Zasady oceny czasopism humanistycznych i ich rola w parametryzacji jednostek naukowych. Nauka, 3, 117-140, dostęp: http://www.pan.poznan.pl/nauki/N_314_07_Kulczycki.pdf

11. Kulczycki, E. (2017). Punktoza jako strategia w grze parametrycznej w Polsce. Nauka i Szkolnictwo Wyższe, 1(49), 63-78. https://doi.org/10.14746/nisw.2017.1.4

12. Kulczycki, E., Drabek, A., Rozkosz, E.A. (2015). Publikacje a zgłoszenia ewaluacyjne, czyli zniekształcony obraz nauki w Polsce. Nauka, 3, 35-58. Pobrane z: https://www.researchgate.net/profile/Emanuel_Kulczycki/publication/280918181_Publikacje_a_zgloszenia_ewaluacyjne_czyli_znieksztalcony_obraz_nauki_w_Polsce/links/55caf4ef08aeca747d69f9e4/Publikacje-a-zgloszenia-ewaluacyjne-czyli-znieksztalcony-obraz-nauki-w-Polsce.pdf

13. Kulczycki, E., Rozkosz, E.A., Drabek A. (2016). Ocena ekspercka jako trzeci wymiar ewaluacji krajowych czasopism naukowych. Nauka, 1, 107-142. Pobrano z: https://www.researchgate.net/publication/292642068_Ocena_ekspercka_jako_trzeci_wymiar_ewaluacji_krajowych_czasopism_naukowych

14. Kwiek, M. (2015). Podzielony uniwersytet. Od deinstytucjonalizacji do reinstytucjonalizacji misji badawczej polskich uczelni. Nauka i Szkolnictwo Wyższe, 2(46), 41-74. https://doi.org/10.14746/ nsw.2015.2.2

15. Leja, K. (2013). Garść refleksji o parametryzacji w nauce i szkolnictwie wyższym. Pobrano z: www.researchgate.net/publication/273633097_Garsc_refleksji_o_parametryzacji_w_nauce_i_szkolnictwie_wyzszym_w_Polsce

16. List Redaktorów ogólnokrajowych czasopism naukowych z wykazu B Ministerstwa Nauki i Szkolnictwa Wyższego (2017). Forum Oświatowe, 30(2), 143-146.

17. Nabout, J.C., Parreira, M.R., Teresa, F.B., Carneiro, F.M., da Cunha, H.F., de Souza Ondei, L., Salomão Caramori, S., Nascimento Soares, T. (2014). Publish (in a group) or perish (alone): the trend from single- to 
multi-authorship in biological papers. Scientometrics, 102(1), 357-364. https://doi.org/10.1007/s11192014-1385-5

18. Ostrowicka, H., Spychalska-Stasiak, J. (2017). Uodpowiedzialnianie akademii - formacje wiedzy i władza parametryzacji w dyskursie akademickim. Nauka i Szkolnictwo Wyższe 1(49), 105-131. https://doi. org/10.14746/nisw.2017.1.6

19. Sieńczyło-Chlabicz, J., Banasiuk, J. (2012). Pojęcie i istota zjawiska autoplagiatu w twórczości naukowej. Państwo i Prawo, 3, 6-19.

20. Sorokowski, P., Kulczycki, E., Sorokowska, A., Pisanski, K. (2017). Predatory journals recruit fake editor. Nature, 543(7646), 481-483. https://doi.org/10.1038/543481a

21. Szadkowski, K. (2015). Uniwersytet jako dobro wspólne. Podstawy krytycznych badań nad szkolnictwem wyższym. PWN, Warszawa.

22. Towpik, E. (2015). IF-mania: Journal Impact Factor nie jest właściwym wskaźnikiem oceny wyników badań naukowych, indywidualnych uczonych ani ośrodków badawczych. Nowotwory. Journal of Onco$\operatorname{logy}, 65(6), 465-475$. Pobrano z: https://journals.viamedica.pl/nowotwory_journal_of_oncology/article/...2015.../3091

23. Toy, J. (2002). The Ingelfinger Rule: Franz Ingelfinger at the New England Journal of Medicine 196777. Science Editor, 25(6), 195-198. Pobrano z: https://www.councilscienceeditors.org/wp-content/ uploads/v25n6p195-198.pdf

24. Walicki, A. (2011). Niebezpieczne nieporozumienia w sprawach nauki. Pobrano z: https://www.tygodnikprzeglad.pl/andrzej-walicki-niebezpieczne-nieporozumienia-sprawach-nauki/

25. Wislar, J., Flanagin, A., Fontanarosa, P.B., DeAngelis, C.D. (2011). Honorary and ghost authorship in high impact biomedical journals: a cross sectional survey. BMJ, 343, 1-7. Pobrano z: https://www.bmj.com/ content $/ \mathrm{bmj} / 343 / \mathrm{bmj} . d 6128$. full.pdf

26. Wróblewski, A.K. (2017). Nie wszystko, co się liczy, da się policzyć... Nauka, 1, 7-22.

27. Zespół do Spraw Dobrych Praktyk Akademickich (2011). Rzetelność w badaniach naukowych oraz poszanowanie własności intelektualnej. Warszawa: MNiSW.

28. www.aje.com/en/arc/ghost-authorship

29. www.ekulczycki.pl/warsztat_badacza/ewaluacja-nauki-w-ustawie-2-0-moj-komentarz-na-kongresie -nauki-w-krakowie

30. www.ekulczycki.pl/warsztat_badacza/wykaz-wydawcow-naukowych-a-model-biznesowy

31. www.springer.com/gp/authors-editors/authorandreviewertutorials/biomed-central-editor-tutorials/ publication-and-research-ethics-and-misconduct/authorship-issues-guest-gift-or-ghost 